\title{
Axotomy Reduces the Effect of Analgesic Opioids Yet Increases the Effect of Nociceptin on Dorsal Root Ganglion Neurons
}

\author{
Fuad A. Abdulla ${ }^{1}$ and Peter A. Smith ${ }^{2}$ \\ ${ }^{1}$ Department of Physical Therapy, Tennessee State University, Nashville, Tennessee 37290, and 2Department of \\ Pharmacology and Division of Neuroscience, University of Alberta, Edmonton, Alberta, Canada T6G 2H7
}

\begin{abstract}
There is some doubt as to the effectiveness of opioids in the management of neuropathic pain. We therefore examined the actions of morphine and the opioid-like peptide nociceptin (both $1 \mu$ ) on dorsal root ganglion (DRG) neurons that were isolated from control or from nerve-injured rats. Both substances reduced $\omega$-conotoxin (CTX) GVIA-sensitive, N-type $\mathrm{Ca}^{2+}$ channel current and small persistent nifedipine/ CTX-insensitive (non-N, non-L type) current. Nifedipinesensitive L-type current was unaffected. The effect of nociceptin was antagonized by naloxone benzoylhydrazone (nalbzoh) but not by naloxone. Sciatic nerve section (axotomy) profoundly reduced the effects of morphine and the $\mu$-receptor agonist D-ala ${ }^{2}, N$-Me-Phe ${ }^{4}$, Gly-ol $^{5}$ enkephalin (DAMGO). The effect of the $\kappa$-agonist $[(+)-(5 \alpha, 7 \alpha, 8 \beta)-N$-methyl- $N-(7-(1-$ pyrrolidinyl)-1oxaspiro(4,5)dec-8-yl)-benzeneacetamide] (U69593) was unchanged, whereas the effect of nociceptin was increased. All agonists produced their strongest effects on the small, putative nociceptive cells and their weakest effects on the largest cells.
\end{abstract}

The $\delta$-receptor agonist, enkephalin D-pen ${ }^{2,5}$ (DPDPE), was without effect on control or on axotomized cells. These and other data suggest that the functional downregulation of $\mu$-opioid receptors on sensory nerves contributes to the poor efficacy of opioids in neuropathic pain. Also, the increased effectiveness of nociceptin after axotomy supports the hypothesis that its actions are mediated via a "non-opioid" receptor. Pronounced suppression of $\mathrm{Ca}^{2+}$ channel current in axotomized DRG neurons by nociceptin led to a reduction in $\mathrm{Ca}^{2+}$ dependent $\mathrm{K}^{+}$conductance and a marked increase in excitability. Despite this, the spinal administration of nociceptin or agonists that activate $\mathrm{ORL}_{1}$ (opioid-like orphan receptor) may prove to be of clinical interest in the management of neuropathic pain.

Key words: sympathetic pain; spinal analgesia; substantia gelatinosa; superficial dorsal horn; C-fiber; causalgia; chronic constriction injury
The spinal analgesic action of opioids involves reduction of neurotransmitter release from primary afferent fibers (Jessell and Iversen, 1977), an effect attributed to suppression of $\mathrm{Ca}^{2+}$ channel current/conductance $\left(I_{\mathrm{Ca}} / g_{\mathrm{Ca}}\right)$ in sensory nerve terminals (Hori et al., 1992). This hypothesis is supported by the observation that opioids suppress high-voltage-activated (HVA) $I_{\mathrm{Ca}}$ or $\mathrm{Ca}^{2+}$-dependent action potentials in the cell bodies of dorsal root ganglion (DRG) neurons (Werz and MacDonald, 1982; Werz et al., 1987; Moises et al., 1994a,b; Taddese et al., 1995; Womack and McCleskey, 1995). Despite the widespread use of opioids in the management of "nociceptive" pain, several clinical studies attest to their poor efficacy in "neuropathic" pain that is sometimes invoked by nerve injury (Arners and Megerson, 1988; Iadarola and Caudle, 1997). Also, immunohistochemical studies have shown that peripheral nerve section (axotomy) reduces the expression of $\mu$ - and $\delta$-opioid receptors in the cell bodies of sensory neurons and in their terminal projections in the dorsal horn (De Groot et al., 1997; Zhang et al., 1998a,b). Thus, limited clinical efficacy in neuropathic pain may involve a reduction in the

\footnotetext{
Received June 4, 1998; revised Sept. 16, 1998; accepted Sept. 17, 1998.

This work was supported by the Alberta Paraplegic Foundation, The Rick Hansen Man-in-Motion Foundation, and the Medical Research Council of Canada. Dr. Abdulla gratefully acknowledges fellowship support from the Alberta Heritage Foundation for Medical Research. We thank Dr. W. F. Colmers and Mr. Tim Moran for their comments on an early version of this manuscript.

Correspondence should be addressed to Dr. Peter A. Smith, Department of Pharmacology, 9.75 Medical Sciences Building, University of Alberta, Edmonton, Alberta, Canada, T6G 2H7.

Copyright (ㄷ) 1998 Society for Neuroscience $\quad 0270-6474 / 98 / 189685-10 \$ 05.00 / 0$
}

ability of opioids to suppress $I_{\mathrm{Ca}}$ in sensory neurons. We therefore examined whether sciatic nerve section (axotomy) reduces the effect of morphine, the selective $\mu$-opioid ligand $\mathrm{D}$-ala ${ }^{2}$, $N$-Me-Phe ${ }^{4}$, Gly-ol $^{5}$ enkephalin (DAMGO), the selective $\delta$-opioid agonist $\delta$-receptor agonist enkephalin D-pen ${ }^{2,5}$ (DPDPE), or the $\kappa$-opioid agonist $[(+)-(5 \alpha, 7 \alpha, 8 \beta)-N$-methyl- $N-(7-(1-$ pyrrolidinyl)-1-oxaspiro(4,5)dec-8-yl)-benzeneacetamide]

(U69593) on HVA $I_{\mathrm{Ca}}\left(I_{\mathrm{Ba}}\right)$ in the cell bodies of DRG neurons.

The limited clinical efficacy of morphine (Arners and Megerson, 1988) is reflected by a weak spinal analgesic effect in animal models of neuropathic pain (Nichols et al., 1995; Ossipov et al., 1995; Yamamoto and Nozaki Taguchi, 1996; Wegert et al., 1997). By contrast, intrathecal injection of the opioid-like peptide nociceptin (orphanin FQ) (Meunier et al., 1995; Reinscheid et al., 1995; Nothacker et al., 1996) attenuates the thermal hyperalgesia produced by partial sciatic nerve injury (Yamamoto et al., 1997). Nociceptin does not interact with $\mu-, \kappa-$, or $\delta$-receptors but is instead an endogenous ligand for the so-called "opioid-like orphan receptor" (ORL $)$ (Meunier et al., 1995; Reinscheid et al., 1995; Nothacker et al., 1996). Effects of nociceptin at $\mathrm{ORL}_{1}$ are antagonized by the peptide [ $\left.\mathrm{Phe}^{1} \psi\left(\mathrm{CH}_{2}-\mathrm{NH}\right) \mathrm{Gly}^{2}\right]$ nociceptin (1-13) $\mathrm{NH}_{2}$ (Guerrini et al., 1998) but not by naloxone (Calo et al., 1997). Naloxone benzoylhydrazone (nalbzoh) is a nonselective nociceptin antagonist that also blocks $\mu$-receptors (Dunnill et al., 1996). Like morphine, nociceptin attenuates HVA $g_{\mathrm{Ca}}$ in DRG neurons (Abdulla and Smith 1997b). It also attenuates glutamatergic transmission in the spinal cord (Faber et al., 1996) and suppresses glutamatergic EPSPs in substantia gelatinosa neu- 
rons (Lai et al., 1997), probably by a presynaptic action on $\mathrm{Ca}^{2+}$ channels in primary afferent terminals (Liebel et al., 1997). Because morphine analgesia is clearly attenuated after peripheral nerve injury (Yamamoto and Nozaki Taguchi, 1996; Wegert et al., 1997) whereas nociceptin continues to be effective [Yamamoto et al. (1997), but see also Hao et al. (1998)], we also examined the effect of axotomy on nociceptin-induced suppression of HVA $g_{\mathrm{Ca}}$ in DRG neurons.

A preliminary report has been published previously (Abdulla and Smith, 1997c).

\section{MATERIALS AND METHODS}

Axotomy. The left sciatic nerve of adult male Sprague Dawley rats $(120-170 \mathrm{gm})$ under sodium pentobarbital anesthesia $(50-55 \mathrm{mg} / \mathrm{kg})$ was sectioned proximal to its bifurcation into the tibial and the peroneal divisions. As described previously (Abdulla and Smith, 1997a), a 5-10 $\mathrm{mm}$ segment of the sciatic nerve was removed to prevent regeneration. Animals were housed in separate cages and examined twice daily for the first $3 \mathrm{~d}$ after surgery and then once daily for any signs of postoperative stress. All protocols were approved by the University of Alberta Health Sciences Animal Welfare Committee.

Electrophysiology. Rats were decapitated, and DRG neurons from L4 and L5 were dissociated as described by White et al. (1989). These ganglia receive the majority of fibers from the sciatic nerve (Swett et al., 1991). Cells were plated into $3 \mathrm{~cm}$ plastic Petri dishes and used for recording within $2-10 \mathrm{hr}$. The cells were superfused with various extracellular solutions at $\sim 2 \mathrm{ml} / \mathrm{min}$. For action potential (AP) recording, external solution contained (in $\mathrm{mm}$ ): $150 \mathrm{NaCl}, 5 \mathrm{KCl}, 2.5 \mathrm{CaCl}_{2}, 1$ $\mathrm{MgCl}_{2}, 10 \mathrm{HEPES}-\mathrm{NaOH}, \mathrm{pH} 7.4$, and 10 D-glucose; (osmolarity, 330$340 \mathrm{mOsm}$ ). Internal solution contained (in mM): 130 potassium gluconate, 2 Mg-ATP, 0.3 Na-GTP, 11 EGTA, 10 HEPES-KOH, pH 7.2, and $1 \mathrm{CaCl}_{2}$, (osmolarity 310-320 mOsm). Single APs were generated using a 2 msec pulse of depolarizing current, and spike width was measured at $50 \%$ of maximum amplitude. Excitability was measured by counting the number of APs that discharged in response to $1 \mathrm{sec}$ pulses of current at threshold strength. $\mathrm{Ba}^{2+}\left(I_{\mathrm{Ba}}\right)$ was used as the charge carrier to record $I_{\mathrm{Ca}}$. For these experiments, external solution contained (in mM): 160 TEA-Cl, 10 HEPES, $2 \mathrm{BaCl}_{2}, 10$ glucose, and $200 \mathrm{~nm}$ TTX, adjusted to $\mathrm{pH} 7.4$ with TEA-OH; internal solution contained (in $\mathrm{mM}$ ): $120 \mathrm{CsCl}_{2}, 5 \mathrm{Mg}$-ATP, $0.4 \mathrm{Na}_{2}$-GTP, 10 EGTA, $20 \mathrm{HEPES}-\mathrm{CsOH}, \mathrm{pH}$ 7.2. $I_{\mathrm{Ba}}$ was evoked at $-10 \mathrm{mV}$ from a holding potential of $-90 \mathrm{mV}$. Leak subtraction procedures were deemed unnecessary (Abdulla and Smith, 1997a). "Maximal outward" $\left(\mathrm{K}^{+}\right)$current was determined form the $I-V$ relationship and recorded at $+70 \mathrm{mV}$ from a $V_{\mathrm{h}}$ of $-90 \mathrm{mV}$ using an external solution that contained (in mM): $145 \mathrm{~N}$-methyl-D-glucamine chloride (NMG-Cl), pH 7.4, $10 \mathrm{KCl}, 2.5 \mathrm{CaCl}_{2}, 10 \mathrm{HEPES}, 1.0 \mathrm{MgCl}_{2}$, and $10 \mathrm{D}$-glucose; internal solution contained (in $\mathrm{mM}$ ): 100 potassium gluconate, 40 NMG-Cl, pH 7.2, 2 Mg-ATP, 0.3 Na-GTP, 11 EGTA, 10 HEPES, and $1.0 \mathrm{CaCl}_{2}$. For recording $\mathrm{Na}^{+}$currents $\left(I_{\mathrm{Na}}\right)$, external solution contained (in mM): $100 \mathrm{NaCl}, 5 \mathrm{KCl}, 4 \mathrm{MgCl}_{2}, 10 \mathrm{HEPES}$, and $60 \mathrm{D}$-glucose, adjusted to $\mathrm{pH} 7.4$ with $\mathrm{NaOH}$; internal solution contained (in mM): $140 \mathrm{CsCl}_{2}, 10 \mathrm{NaCl}, 2 \mathrm{Mg}$-ATP, $0.3 \mathrm{Na}-\mathrm{GTP}, 2$ EGTA, 10 HEPES, and $2 \mathrm{MgCl}_{2}$, adjusted to pH 7.2 with $\mathrm{NaOH}$.

Whole-cell recordings were made at $22^{\circ} \mathrm{C}$ using an Axoclamp $2 \mathrm{~A}$ amplifier in discontinuous voltage-clamp or bridge-balance currentclamp mode. Borosilicate glass patch electrodes had DC resistance of 4-6 $\mathrm{M} \Omega$ for AP recording or 1-3 $\mathrm{M} \Omega$ for current recording. Sampling rates of $30-60 \mathrm{kHz}$ and clamp gains $>25 \mathrm{nA} / \mathrm{mV}$ could be attained with these low-resistance electrodes. Because the discontinuous voltage-clamp method allows the cell to be clamped to the measured membrane voltage, it circumvents some of the series resistance problems that could be encountered if a conventional patch-clamp amplifier had been used. Because we did not use leak subtraction and appropriate compensation circuitry is not available in the Axoclamp $2 \mathrm{~A}$ amplifier, the illustrated data records, which were filtered to $-3 \mathrm{~dB}$ at 1 or $3 \mathrm{kHz}$, display large capacitance transients. Under current-clamp, input capacitance $\left(C_{\text {in }}\right)$ was calculated from the input resistance $\left(R_{\text {in }}\right)$ and the membrane time constant $\left(\tau_{\mathrm{m}}\right)$ using the equation $\tau_{\mathrm{m}}=C_{\mathrm{in}} \cdot R_{\mathrm{in}}$. Under voltage clamp, $C_{\mathrm{in}}$ was measured by integrating the area of capacitative current transients that were generated by $10 \mathrm{mV}$ commands $(\Delta \mathrm{V})$. This yielded the charge $Q$ that is related to $C_{\text {in }}$ by $Q=\Delta \mathrm{V} \cdot C_{\text {in }}$. Data were acquired and analyzed using Pclamp 5.5.1. software, and final records were produced using Microcal Origin 4.1 or 5.0. Drugs were applied by superfusion, and all data are presented as means \pm SEM. Statistical significance was assessed by Student's unpaired $t$ test or $\chi^{2}$ as appropriate. Agonist-induced percentage changes in $I_{\mathrm{Ba}}$ and outward current are calculated only from those cells that responded. Thus, nonresponding cells that would have $0 \%$ change in $I_{\mathrm{Ba}}$ or maximal outward current are excluded from the statistical analysis. This approach was not feasible for description of changes in excitability because the smallest possible change, i.e., a change from one spike to two spikes, would be recorded as a $100 \%$ increase in excitability. Data for excitability changes are therefore collected from all cells, and nonresponders are entered into the averages as exhibiting a $0 \%$ increase in excitability. Data on the percentage of cells responding to agonists in each category are presented separately. DRG cells were classified into "large," "medium," and "small" subtypes on the basis of their AP shape and/or $C_{\text {in }}$ according to previously defined criteria (Abdulla and Smith 1997a). The large cells were defined as those with AP duration $<3 \mathrm{msec}$ and $C_{\mathrm{in}}$ of $>90 \mathrm{pF}$; medium cells had an AP duration of 3-5 msec, $C_{\text {in }}$ of $70-90 \mathrm{pF}$, and an "inflection" on the falling phase of AP; and the small cells had an AP duration $>5 \mathrm{msec}, C_{\mathrm{in}}$ of $<70 \mathrm{pF}$, and a large inflection or "shoulder" on the falling phase.

Drugs and chemicals. Nociceptin (rat or human; Phe-Gly-GlyPhe-Thr-Gly-Ala-Arg-Lys-Ser-Ala-Arg-Lys-Leu-Ala-Asn-Gln) was from Peptide Institute (Louisville, KY); naloxone hydrochloride, nalbzoh, $\omega$-conotoxin (CTX) GVIA, DAMGO, DPDPE, and U69593 were from Research Biochemicals International (Natick, MA), morphine sulfate was from British Drug Houses (Toronto, Canada), and all other chemicals and drugs were from Sigma (St. Louis, MO).

\section{RESULTS}

\section{Effects of morphine and nociceptin on $I_{\mathrm{Ba}}$ before and after axotomy}

In neurons from control rats, morphine $(1 \mu \mathrm{M})$ was less effective on large cells than on medium or small cells. It inhibited $I_{\mathrm{Ba}}$ in only 4 of 32 control large cells by $22.6 \pm 2.1 \%$, in 13 of 36 control medium cells by $26.9 \pm 1.6 \%$, and in 21 of 41 small cells by $35.5 \pm$ $2.0 \%$. Two to 4 weeks after axotomy, the inhibitory effects of morphine on $I_{\mathrm{Ba}}$ were reduced. Therefore, morphine reduced $I_{\mathrm{Ba}}$ in 3 of 40 axotomized large cells by $21.2 \pm 1.9 \%$, in 6 of 47 medium cells $(p<0.02)$ by $17.8 \pm 1.8 \%(p<0.002)$, and in 16 of 61 small cells $(p<0.01)$ by $23.2 \pm 1.9 \%(p<0.001)$.

Like morphine, nociceptin $(1 \mu \mathrm{M})$ exerted weak effects on large control cells and stronger effects on medium and small cells. It inhibited $I_{\mathrm{Ba}}$ in 3 of 30 control large cells by $23.3 \pm 3.9 \%$, in 14 of 36 medium cells by $26.2 \pm 1.3 \%$, and in 21 of 41 small cells by $34.7 \pm 1.9 \%$. By contrast with the reduced effect of morphine seen after axotomy, the effects of nociceptin were increased. Thus, nociceptin reduced $I_{\mathrm{Ba}}$ in 6 of 40 axotomized large cells by $29.0 \pm 1.5 \%$, in 29 of 46 medium cells $(p<0.03)$ by $37.9 \pm 2.1 \%$ $(p<0.001)$, and in 45 of 60 small cells $(p<0.02)$ by $48.4 \pm 2.0 \%$ $(p<0.001)$.

In most experiments, morphine and nociceptin were applied to the same cell, and their relative effects were examined. Both drugs (at $1 \mu \mathrm{M}$ ) produced similar amounts of $I_{\mathrm{Ba}}$ suppression in small, medium, and large control cells. After axotomy, however, the response of any one cell to nociceptin was larger than its response to morphine. Some typical data records are illustrated in Figure $1 A$. Figure $1 A_{1}$ illustrates superimposed recordings of $I_{\mathrm{Ba}}$ obtained from the same small cell before and after superfusion of morphine or nociceptin (both $1 \mu \mathrm{M}$ ). The amount of $I_{\mathrm{Ba}}$ suppression induced by morphine is very similar to that induced by nociceptin. Figure $1 A_{2}$ illustrates recordings from an axotomized small cell. The effect of morphine is small compared with the effect of nociceptin. The data from these two cells are summarized in Figure $1 B$. This shows the time course of the suppression of $I_{\mathrm{Ba}}$ by both drugs in both cells. The enhanced effect of nociceptin and the reduced effect of morphine in the axotomized cell can be clearly seen. Figure $1 C$ summarizes the percentage sup- 


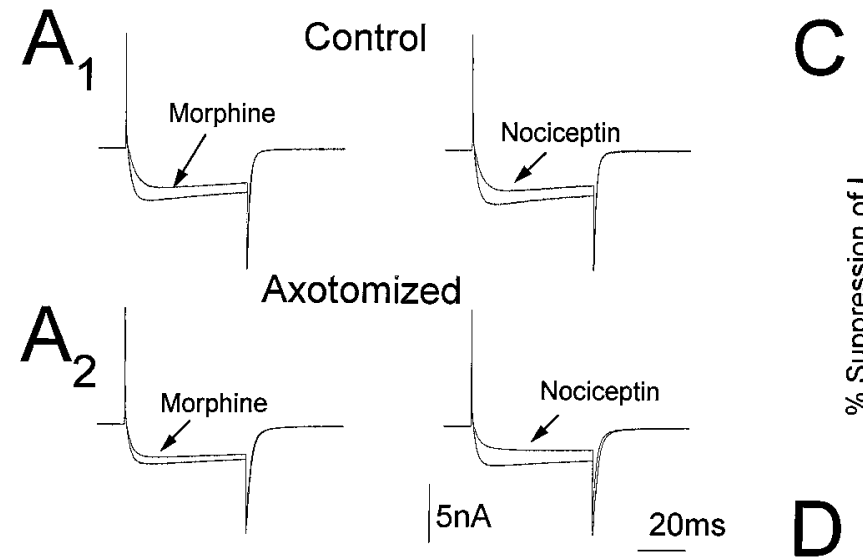

B

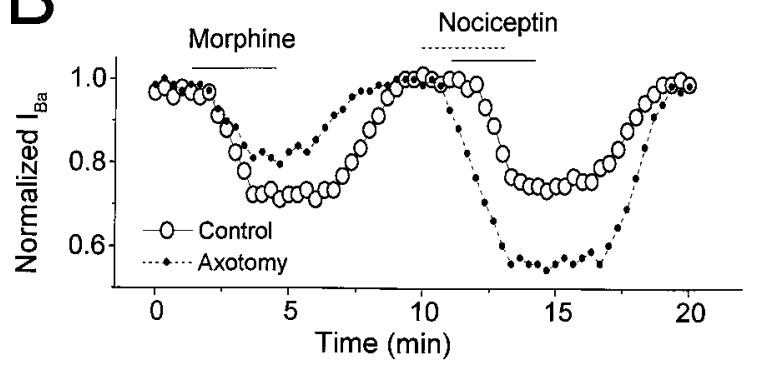

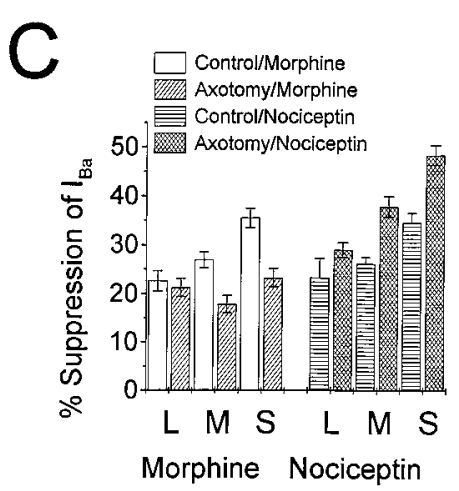

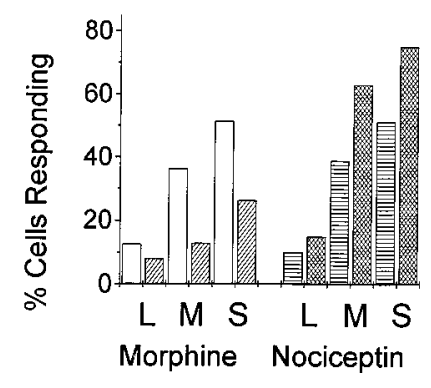

Figure 1. Effects of morphine and nociceptin on $I_{\mathrm{Ba}}$ in DRG cells. $A$, Sample records from small cells from control $\left(A_{1}\right)$ and axotomized $\left(A_{2}\right)$ animals. Currents were recorded at $-10 \mathrm{mV}$ from a $\mathrm{V}_{\mathrm{h}}$ of $-90 \mathrm{mV}$. Tails were recorded at $-40 \mathrm{mV}$, and voltage records were omitted for clarity. Both morphine and nociceptin decreased $I_{\mathrm{Ba}}$ in the cells illustrated both before and after axotomy. Note that the $I_{\mathrm{Ba}}$ suppression induced by $1 \mu \mathrm{M}$ morphine was similar to that induced by nociceptin in the control cell, whereas in the axotomized cell the effect of morphine was decreased and that of nociceptin was increased. $B$, Time course of the effects of morphine or nociceptin on cells illustrated in $A_{1}$ and $A_{2}$ (data normalized). $C$, Graphs to show percentage suppression of $I_{\mathrm{Ba}}$ in large $(L)$, medium $(M)$, and small $(S)$ neurons from control or axotomized animals in response to $1 \mu \mathrm{M}$ morphine or nociceptin. $D$, Graphs show percentage of cells in each category responding to $1 \mu \mathrm{M}$ morphine or to $1 \mu \mathrm{M}$ nociceptin before or after axotomy.

Table 1. Comparison of the effects of $\mu$-, $\delta$-, and $\kappa$-agonists on $I_{\mathrm{Ba}}$ suppression before and after axotomy

\begin{tabular}{|c|c|c|c|c|c|c|}
\hline \multirow[b]{2}{*}{ Agonist type } & \multicolumn{2}{|l|}{$\mu(\mathrm{DAMGO})$} & \multicolumn{2}{|l|}{$\kappa(\mathrm{U} 69593)$} & \multicolumn{2}{|l|}{$\delta$ (DPDPE) } \\
\hline & $\begin{array}{l}\text { Number of cells } \\
\text { inhibited }\end{array}$ & $\%$ inhibition & $\begin{array}{l}\text { Number of cells } \\
\text { inhibited }\end{array}$ & $\%$ inhibition & $\begin{array}{l}\text { Number of cells } \\
\text { inhibited }\end{array}$ & $\%$ inhibition \\
\hline \multicolumn{7}{|l|}{ Cell group } \\
\hline Control large cells & $2 / 21$ & $22.9 \pm 3.6 \%$ & $1 / 17$ & $18.4 \%$ & $0 / 15$ & 0 \\
\hline Axotomized large cells & 1/18 (n.s.) & $20.6 \%$ (n.s.) & 2/19 (n.s.) & $22.5 \pm 2.1 \%$ (n.s.) & 0/12 (n.s.) & 0 \\
\hline Control medium cells & $14 / 24$ & $28.0 \pm 1.9 \%$ & $9 / 21$ & $30.4 \pm 2.0 \%$ & $0 / 20$ & 0 \\
\hline Axotomized medium cells & $\begin{array}{l}3 / 21 \\
(p<0.05)\end{array}$ & $\begin{array}{l}18.5 \pm 2.8 \% \\
(p<0.02)\end{array}$ & 8/18 (n.s.) & $29.9 \pm 2.2 \%$ (n.s.) & 0/21 (n.s.) & 0 \\
\hline Control small cells & $15 / 25$ & $34.8 \pm 2.3 \%$ & $14 / 24$ & $33.7 \pm 2.1 \%$ & $0 / 21$ & 0 \\
\hline Axotomized small cells & $\begin{array}{l}5 / 24 \\
(p<0.01)\end{array}$ & $\begin{array}{l}22.6 \pm 2.3 \% \\
(p<0.003)\end{array}$ & $12 / 20$ (n.s.) & $33.7 \pm 2.0 \%$ (n.s.) & 0/18 (n.s.) & 0 \\
\hline
\end{tabular}

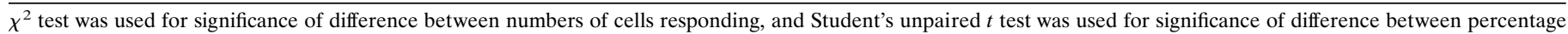
inhibition of $\mathrm{I}_{\mathrm{Ba}}$ before and after axotomy. Percentage inhibition was calculated only from responding cells. n.s., Not significant.

pression of $I_{\mathrm{Ba}}$ induced by morphine or nociceptin in small $(S)$, medium $(M)$, and large $(L)$ cells before and after axotomy, and Figure $1 D$ shows the percentage of cells responding in each category. These graphs reemphasize the preferential effects of the drugs on the small cells and the decrease in effectiveness of morphine and the increased effectiveness of nociceptin after axotomy.

\section{Effects of $\mu-, \delta-$, and $\kappa$-agonists before and after axotomy}

To better characterize the effect of axotomy on the morphine response, we examined changes in $I_{\mathrm{Ba}}$ suppression by the selective $\mu$-agonist DAMGO, the selective $\delta$-agonist DPDPE, and the selective $\kappa$-agonist U69593. The results are shown in Table 1 . The $\delta$-agonist DPDPE $(1 \mu \mathrm{M})$ was without effect on $I_{\mathrm{Ba}}$ on control DRG cells. It also failed to affect small, medium, or large cells after axotomy. By contrast, the $\mu$-agonist DAMGO and the $\kappa$-agonist U69593 (both $1 \mu \mathrm{M}$ ) produced pronounced $I_{\mathrm{Ba}}$ suppres- sion in small control cells and moderate effects on medium and large cells. After axotomy, however, the effects of the $\mu$-agonist, DAMGO were significantly reduced, whereas those of the $\kappa$-agonist U69593 were essentially unchanged. Typical experiments are illustrated in Figure 2. Figure $2 A$ show superimposed recordings of $I_{\mathrm{Ba}}$ from the same control small cell before and during application of DAMGO, U69593, or DPDPE (all $1 \mu \mathrm{M}$ ). The current is suppressed by the $\mu$ - and $\kappa$-agonists but not by the $\delta$-agonist. Figure $2 B$ illustrates a similar series of records obtained from an axotomized small cell. DAMGO produces very modest suppression of $I_{\mathrm{Ba}}$, the effect of U69593 is comparable to that seen in a control cell, and the $\delta$-agonist DPDPE is without effect.

\section{Effects of $\omega$-conotoxin GVIA and dihydropyridines on responses to nociceptin and morphine}

Agonists at $\mu$-opioid receptors such as PL017 (Tyr-Pro-NMePheD-Pro- $\left.\mathrm{NH}_{2}\right)$ inhibit N-type $I_{\mathrm{Ca}}\left(I_{\mathrm{Ca}, \mathrm{N}}\right)$ in rat DRG neurons. In 


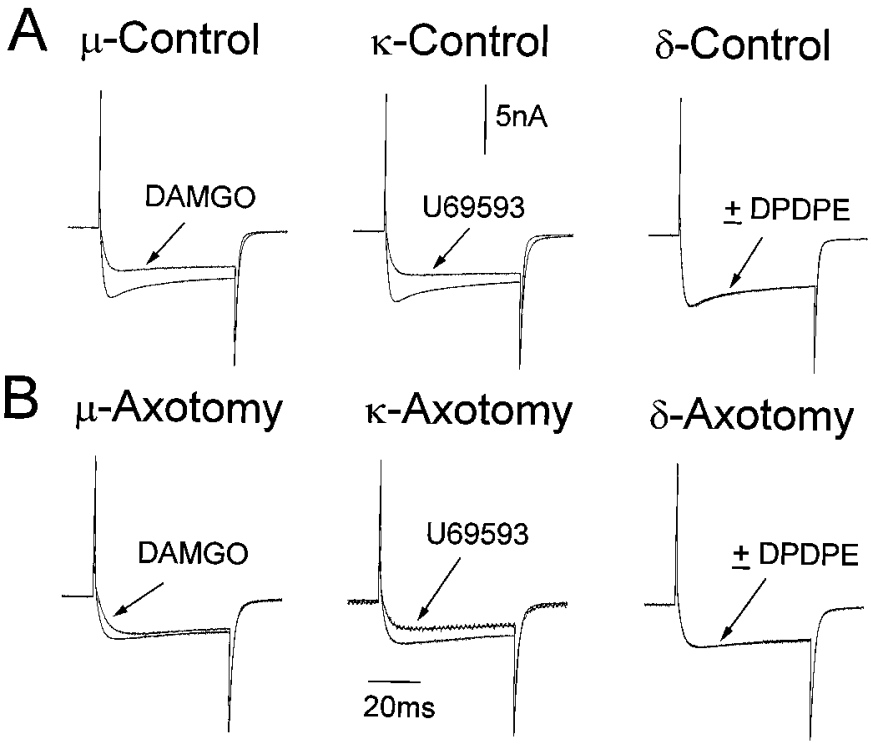

Figure 2. Effects of $\mu$-, $\kappa$-, and $\delta$-agonists on $I_{\mathrm{Ba}}$ in control and axotomized DRG cells. $A$, Effects of the $\mu$-agonist DAMGO and the $\kappa$-agonist U69593 and the lack of effect of the $\delta$-agonist DPDPE (all $1 \mu \mathrm{M}$ ) on a small cell from a control animal. $B$, Effects of the same three agonists on a small cell from an axotomized animal. Note small response to DAMGO and lack of effect of DPDPE. The response to U69593 is similar to that seen in the control cell. Current and time calibrations refer to all records. Currents evoked at $-10 \mathrm{mV}$ from $V_{\mathrm{h}}=-90 \mathrm{mV}$. Each panel shows superimposed recordings of $I_{\mathrm{Ba}}$ evoked before and during superfusion of drugs. Voltage command trace was omitted for clarity.

some cells, this agonist also attenuates a sustained component of the current that is insensitive to both $\omega$-CTX GVIA and nifedipine (Moises et al., 1994b; Rusin and Moises, 1995). To characterize which components of $\mathrm{HVA} g_{\mathrm{Ba}}$ in small cells were affected by nociceptin and morphine, we examined the effect of $\omega$-CTX GVIA $(1 \mu \mathrm{M} ; n=5)$ and nifedipine $(2 \mu \mathrm{M} ; n=4)$. As might be expected, the effects of morphine, which acts primarily on $\mu$-opioid receptors (Martin, 1983; Paternak, 1993), were similar to those of PL017. The effects of nociceptin were indistinguishable from those of morphine. Typical experiments are illustrated in Figure 3. Those illustrated in Figure $3 A, C$ show that morphine and nociceptin do not affect L-type $I_{\mathrm{Ba}}\left(I_{\mathrm{Ba}, \mathrm{L}}\right)$. Morphine or nociceptin $(1 \mu \mathrm{M})$ reduced $I_{\mathrm{Ba}}$ at $-10 \mathrm{mV}$ by a similar amount in the presence or absence of $2 \mu \mathrm{M}$ nifedipine. The experiments illustrated in Figure $3 B, D$ show that morphine and nociceptin inhibit $I_{\mathrm{Ba}, \mathrm{N}}$ as well as another small, noninactivating, $\omega$-CTX GVIA-resistant current. The marked reduction of $I_{\mathrm{Ba}}$ at $-10 \mathrm{mV}$ induced by $1 \mu \mathrm{M}$ morphine or nociceptin was attenuated by $\omega$-CTX GVIA. Because suppression of current was still seen under these conditions, morphine and nociceptin must act on a current other than $I_{\mathrm{Ba}, \mathrm{N}}$. This current is not $I_{\mathrm{Ba}, \mathrm{L}}$ (Fig. 3A,C), so it is concluded that both agonists act on a nifedipine/ $\omega$-CTX GVIA-resistant current (Rusin and Moises, 1995). The lack of complete blockade of the effect of effects of morphine and nociceptin by $\omega$-CTX GVIA cannot be attributable to use of a submaximal concentration of toxin, because $1 \mu \mathrm{M}$ CTX GVIA blocks all effects of noradrenaline on $I_{\mathrm{Ba}}$ in axotomized DRG neurons (Abdulla and Smith, 1997a).

\section{Effects of morphine and nociceptin on the excitability of DRG cells}

Noradrenaline and neuropeptide Y (NPY) suppress $g_{\mathrm{Ba}, \mathrm{N}}$ in DRG neurons (Abdulla and Smith, 1997a,b, 1999) in much the same way as nociceptin and morphine. In the case of noradrenaline, this effect is only seen after axotomy, and in the case of NPY the effect is much greater after axotomy. Suppression of $g_{\mathrm{Ca}, \mathrm{N}}$ leads to attenuation of $\mathrm{Ca}^{2+}$-sensitive $\mathrm{K}^{+}$conductance(s) $\left(g_{\mathrm{K}, \mathrm{Ca}}\right)$ and increases in excitability that may contribute to spontaneous activity in injured sensory nerves (Abdulla and Smith, 1997a, 1999). We therefore examined whether nociceptin and morphine can also increase excitability of DRG cells and how these effects might be changed after axotomy.

AP discharge was invoked using a $1 \mathrm{sec}$ pulse of current at the threshold strength in the presence or absence of morphine or nociceptin (both $1.0 \mu \mathrm{M}$ ). Figure $4 A_{1}$ illustrates typical increases in excitability induced by morphine and nociceptin on the same small control cell. Morphine and nociceptin produced comparable effects in control cells at this concentration, and the relative sensitivity of cell types paralleled that seen with effects on $I_{\mathrm{Ba}}$. Thus, large cells were affected less frequently and to a lesser extent than medium or small cells. Morphine increased the firing rate of only 1 of 26 control large cells, whereas nociceptin increased the firing rate of 2 of 24 cells. Morphine increased the excitability of 17 of 36 medium control cells by $42.3 \%$ and of 17 of 36 small cells by $50.9 \%$. Similarly, nociceptin increased the excitability of 16 of 36 medium cells by $41.7 \%$ and of 17 of 35 small cells by $49.5 \%$. Two to 4 weeks after axotomy, the effects of morphine on excitability were reduced. Morphine increased the excitability of 1 of 25 large cells by $2.6 \%, 7$ of 32 medium cells $(p<0.03)$ by $31.3 \%$, and 10 of 41 small cells $(p<0.04)$ by $17.3 \%$ ( $p$ values from $80 \chi^{2}$ tests to compare number of cells of each type affected before or after axotomy).

By contrast, the effects of nociceptin on excitability were increased after axotomy. At $1 \mu \mathrm{M}$ it increased the excitability of 5 of 25 large cells by $24.0 \%, 23$ of 32 medium cells $(p<0.025)$ by $89.8 \%$, and 30 of 40 small cells $(p<0.02)$ by $111.7 \%$ ( $p$ values from $80 \chi^{2}$ tests to compare number of cells of each type affected before or after axotomy). This finding is consistent with the observed increased effectiveness of nociceptin in suppressing $I_{\mathrm{Ba}}$ after axotomy (Fig. 1).

Figure $4 A_{2}$ illustrates the small effect of morphine on the excitability of a small axotomized cell and the profound increase in excitability produced by nociceptin in the same cell. The data from these two cells are summarized in Figure $4 B$, which shows the time course of the increase in excitability induced by both drugs. The enhanced effect of nociceptin and the reduced effect of morphine in the axotomized cell can be clearly seen. Figure $4 C$ summarizes the percentage increase in number of APs (spikes) induced by morphine or nociceptin in control small $(S)$, medium $(M)$, and large $(L)$ cells before and after axotomy, and Figure $4 D$ shows the percentage of cells responding in each category. These graphs reemphasize the preferential effects of the drugs on the small cells and the decrease in effectiveness of morphine and the increased effectiveness of nociceptin after axotomy.

\section{Pharmacology of the effects of morphine and nociceptin}

The effect of morphine on $I_{\mathrm{Ba}}$ and on excitability of DRG cells excitability was antagonized by the broad spectrum $\mu-, \delta$-, and $\kappa$-opioid antagonist naloxone ( $1 \mu \mathrm{M} ; n=4$ for both). Effects mediated via $\mathrm{ORL}_{1}$ receptors are unaffected or relatively insensitive to inhibition by naloxone (Connor et al., 1996a,b; Faber et al., 1996; Calo et al., 1997). In agreement with this, naloxone (up to $1 \mu \mathrm{M})$ failed to antagonize the effects of nociceptin on $I_{\mathrm{Ba}}(n=$ 4 ) or on excitability $(n=4)$. On the other hand, the $\kappa_{3}$-agonist 
nalbzoh has been reported to exert an antagonist action at $\mathrm{ORL}_{1}$ receptors (Dunnill et al., 1996). Nalbzoh $(1 \mu \mathrm{M})$ antagonized the effects of nociceptin on excitability $(n=4)$ and on $I_{\mathrm{Ba}}(n=5)$. Nalbzoh also has significant antagonist action at $\mu$-opioid receptors (Dunnill et al., 1996), and we found that it antagonized the actions of morphine on $I_{\mathrm{Ba}}(n=4)$ and on excitability $(n=4)$. We have not yet tested whether the peptide $\left[\mathrm{Phe}^{1} \psi\left(\mathrm{CH}_{2}-\mathrm{NH}\right) \mathrm{Gly}^{2}\right]$ nociceptin (1-13) $\mathrm{NH}_{2}$ (Guerrini et al., 1998) can selectively antagonize nociceptin responses on DRG neurons.

\section{Effects of morphine and nociceptin on $\mathrm{K}^{+}$and $\mathrm{Na}^{+}$currents}

It has been assumed that the increase in excitability induced by nociceptin and morphine result from suppression of $g_{\mathrm{K}, \mathrm{Ca}}$ as a consequence of their action on $g_{\mathrm{Ca}, \mathrm{N}}$. To test this, we examined their effect on $\mathrm{Ca}^{2+}$-sensitive and $\mathrm{Ca}^{2+}$-insensitive components of the maximal outward current at $+70 \mathrm{mV}$. This current reflects outward movement of $\mathrm{K}^{+}$through delayed-rectifier $\left(I_{\mathrm{K}}\right)$, A-type $\mathrm{K}^{+}$channels and through $g_{\mathrm{K}, \mathrm{Ca}}$ channels (Akins and McCleskey, 1993). Both morphine and nociceptin $(1 \mu \mathrm{M})$ decreased the maximal outward current (at $+70 \mathrm{mV}$ from $\mathrm{V}_{\mathrm{h}}=-90 \mathrm{mV}$ ). In control cells, morphine decreased the total outward current in 2 of 23 large cells by $18.8 \pm 2.2 \%, 13$ of 33 medium cells by $23.4 \pm 1.7$, and in 17 of 32 small cells by $25.5 \pm 1.4 \%$. Similarly, nociceptin reduced the maximal outward current in 2 of 21 control large cells by $19.6 \pm 4.4 \%, 12$ of 31 medium cells by $23.8 \pm 2.0 \%$, and 16 of 32 small cells by $25.8 \pm 1.6 \%$. After axotomy, the effects of morphine on maximal outward current were decreased, and the effects of nociceptin were increased. Thus morphine decreased the total outward current in 2 of 27 large cells by $16.4 \pm 2.0 \%$, in 5 of 30 medium cells $(p<0.05)$ by $18.0 \pm 1.2 \%(p<0.02)$, and in 9 of 35 small cells by $19.0 \pm 1.6 \%(p<0.007)$, whereas nociceptin reduced it in 4 of 45 large cells by $22.0 \pm 3.0 \%, 20$ of 30 medium cells $(p<0.03)$ by $30.5 \pm 1.4 \%(p<0.01)$, and in 26 of 35 small cells $(p<0.04)$ by $33.6 \pm 1.7 \%(p<0.002)$.

The $\mathrm{Ca}^{2+}$ channel blocker $\mathrm{Cd}^{2+}(0.5$ or $1.0 \mathrm{~mm})$ reduced total outward current recorded at $+70 \mathrm{mV}$ and occluded the effects of morphine and nociceptin (both at $1 \mu \mathrm{M}$ ) on the current that remained $\left(V_{\mathrm{h}}=-90 \mathrm{mV} ; n=10-15\right.$ for each cell type, for both morphine and nociceptin from control and axotomized animals). This shows that the actions of morphine and nociceptin are exerted on $g_{\mathrm{K}, \mathrm{Ca}}$ because these currents that depend on $\mathrm{Ca}^{2+}$ influx are blocked by the extracellular application of $\mathrm{Cd}^{2+}$.

Some typical experiments are illustrated in Figure $5 \mathrm{~A}$. Illustrations of maximal outward current in a small cell recorded before and during application of $1 \mu \mathrm{M}$ morphine or nociceptin are shown in Figure $5 A_{1}$. Both agonists produce similar amounts of suppression of the current. In the presence of $0.5 \mathrm{mM} \mathrm{Cd}^{2+}$, the effects of both agonists are blocked. Figure $5 A_{2}$ illustrates a similar experiment performed on an axotomized small cell. Nociceptin is clearly more effective than morphine, and the effects of both drugs are prevented by $\mathrm{Cd}^{2+}$. Figure $5 B$ summarizes the time course data from the experiments performed on the two cells shown in Figure $5 A_{1}, A_{2}$. The similar effects of both drugs on the control cell is clearly seen as is the large effect of nociceptin and the small effect of morphine after axotomy. Figure $5 C$ summarizes the data from all cells that responded. Again the decreased effectiveness of morphine and the increased effectiveness of nociceptin after axotomy can be seen. This trend is also apparent from Figure $5 D$, which illustrates the percentage of cells responding to each drug before and after axotomy. As with $I_{\mathrm{Ba}}$ and with excitability changes, both nociceptin and morphine exert their strongest effects on small cells and their weakest effects on large cells. Also the differential effects of axotomy on responses of outward current to morphine and nociceptin parallel those seen with $I_{\mathrm{Ba}}$ and with excitability.

Neither morphine nor nociceptin $(1 \mu \mathrm{M})$ affected $I_{\mathrm{Na}}$ in any of the cell types either before or after axotomy. Experiments were performed on 61 cells from control animals and on 54 cells from axotomized animals.

\section{DISCUSSION}

The primary finding of this work is that morphine becomes less effective and nociceptin becomes more effective in suppressing $I_{\mathrm{Ca}, \mathrm{N}}$ in DRG cell bodies after axotomy. These findings contribute to the understanding of the weak clinical efficacy of morphine in neuropathic pain. In addition, they lend support to the idea that spinal administration of nociceptin may prove of use in the management of nerve injury-induced pain, which is typically chronic and often intractable.

Because effects mediated via $\kappa$-receptors are unchanged by axotomy and neither control nor axotomized cells respond to $\delta$-agonists, attenuation of the effect of morphine results from reduction of effects mediated through $\mu$-receptors. This conclusion, which is supported by the observed decreased effectiveness of DAMGO, presumably reflects downregulation of $\mu$-receptor expression (Zhang et al., 1998b). Because axotomy reduces $\mu$-receptor-like immunoreactivity both in DRG cell bodies and in the dorsal horn of the spinal cord (De Groot et al., 1997; Zhang et al., 1998b), we suggest that the limited effectiveness of morphine as a spinal analgesic in nerve injury models results from impairment of its ability to suppress $I_{\mathrm{Ca}}$ in sensory nerve terminals. This possibility now needs to be examined more directly by testing whether nerve injury impedes opioid-induced suppression of excitatory synaptic transmission in the superficial laminae of the dorsal horn (Hori et al., 1992).

The lack of the effect of the $\delta$-agonist DPDPE on $I_{\mathrm{Ba}}$ in control neurons confirms previous findings from other laboratories (Schroeder et al., 1991; Moises et al., 1994b) and fits with observation that $\delta$-opioid receptor-like immunoreactivity is localized intracellularly to the Golgi complex and to vesicular membranes in DRG neurons (Zhang et al., 1998a).

The observation that axotomy decreases or fails to alter responsiveness to $\mu$-, $\delta$-, or $\kappa$-opioids yet selectively increases responsiveness to nociceptin strongly supports the hypothesis that it acts at a "nonopioid" receptor (Guerrini et al., 1998), presumably $\mathrm{ORL}_{1}$ (Meunier et al., 1995; Reinscheid et al., 1995; Nothacker et al., 1996; Henderson and McKnight, 1997). Our findings also raise the possibility that injury increases the effectiveness of nociceptin at primary afferent terminals. Two recent reports are consistent with this. Jia et al. (1998) found increased nociceptin binding in dorsal horn in inflammatory pain (complete Freund's adjuvantrat hindpaw model), and Yamamoto et al. (1997) reported that nociceptin attenuates thermal hyperalgesia induced by unilateral sciatic nerve constriction in rats. It is therefore now necessary to test directly whether nerve injury increases the ability of nociceptin to attenuate synaptic transmission in the dorsal horn (Lai et al., 1997; Liebel et al., 1997). Such experiments may also resolve the findings of Yamamoto et al. (1997) and Jia et al. (1998) with those of Hao et al. (1998) who reported attenuation of nociceptininduced analgesia in two different neuropathic pain models. Despite this inconsistency, which may devolve from the different types of pain models used, the possible use of nociceptin as a 
A
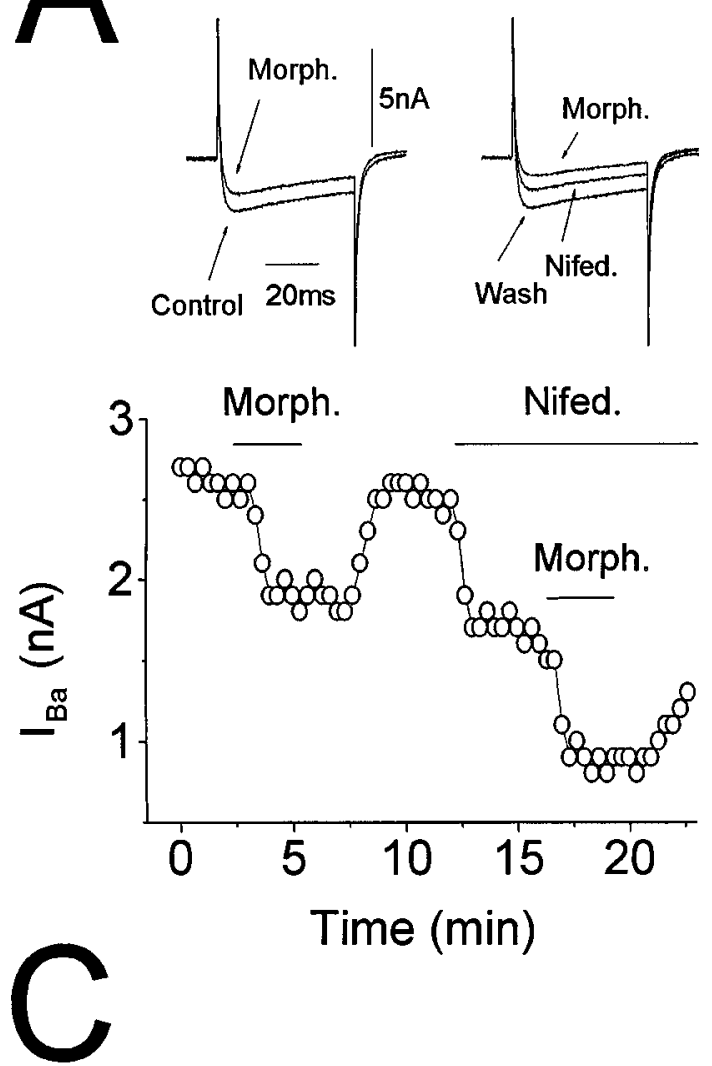

Nifed.

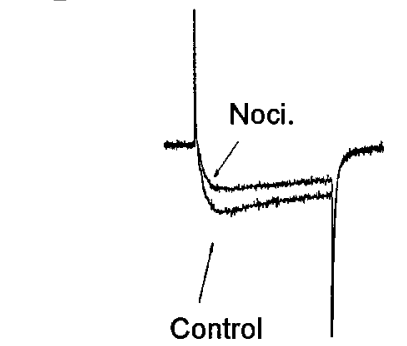

Control

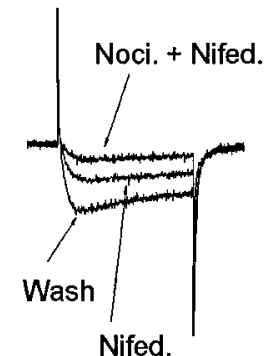

Nifed.
B

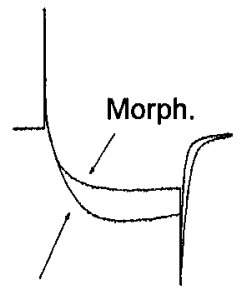

Control

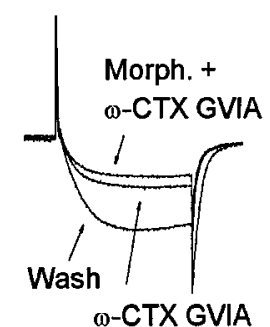

$\omega$-CTX GVIA
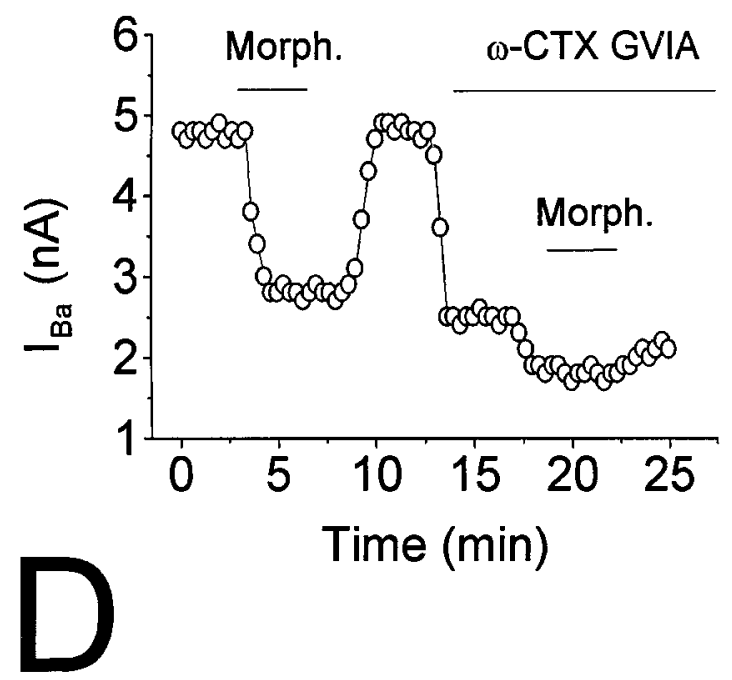

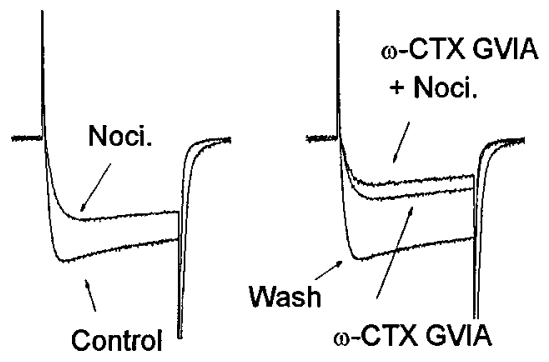

Noci.

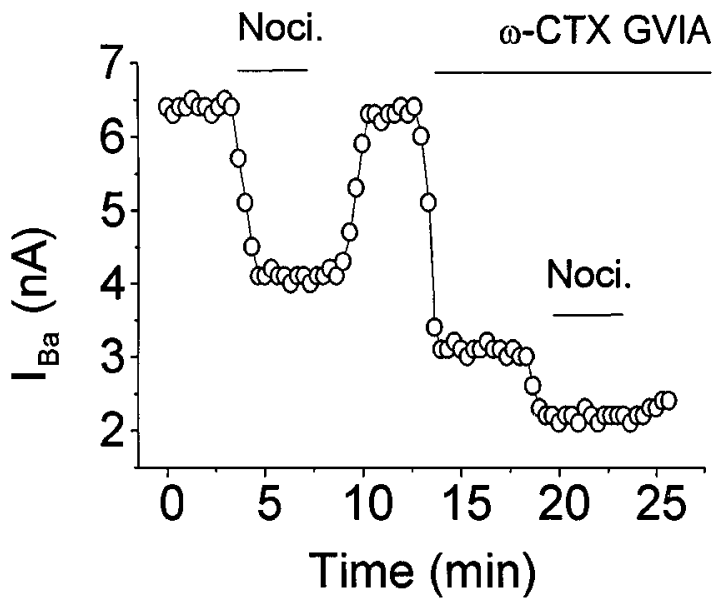

Figure 3. Effects of $\omega$-CTX GVIA and nifedipine on $I_{\mathrm{Ba}}$ suppression induced by morphine and nociceptin. Superimposed current records in all parts of the figure are $I_{\mathrm{Ba}}$ responses to a step to $-10 \mathrm{mV}$ from a $V_{\mathrm{h}}$ of $-90 \mathrm{mV}$ in the presence and absence of morphine or nociceptin (both $1 \mu \mathrm{M}$ ) and/or nifedipine $(2 \mu \mathrm{M})$ or $\omega$-CTX GVIA $(1 \mu \mathrm{M})$. Time and current calibration in first record applies to all traces; voltage records were omitted for clarity. $A$, Left-hand data records show suppression of current by morphine. Right-hand data records comprise superimposed wash response (Wash) and current recorded in the presence of nifedipine and again in the presence of morphine plus nifedipine. The amount of (Figure legend continues) 


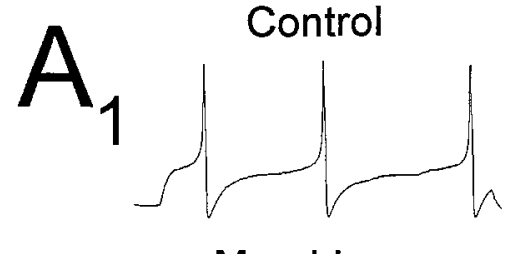

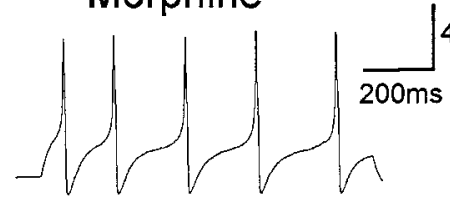

Axotomized

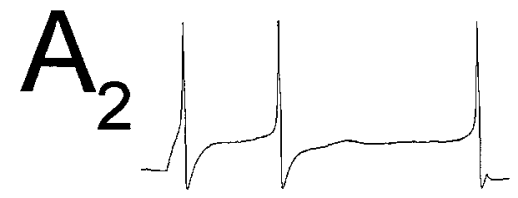

Morphine/Axotomized

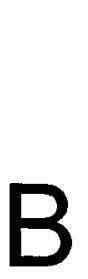

Morphine

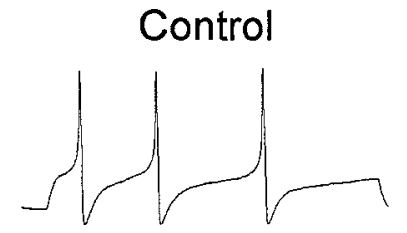

Nociceptin

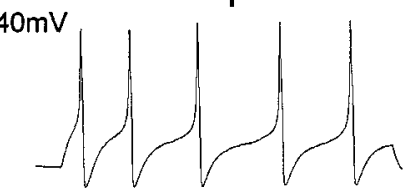

Axotomized

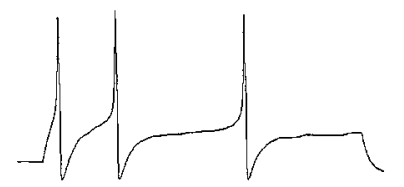

Nociceptin/Axotomized
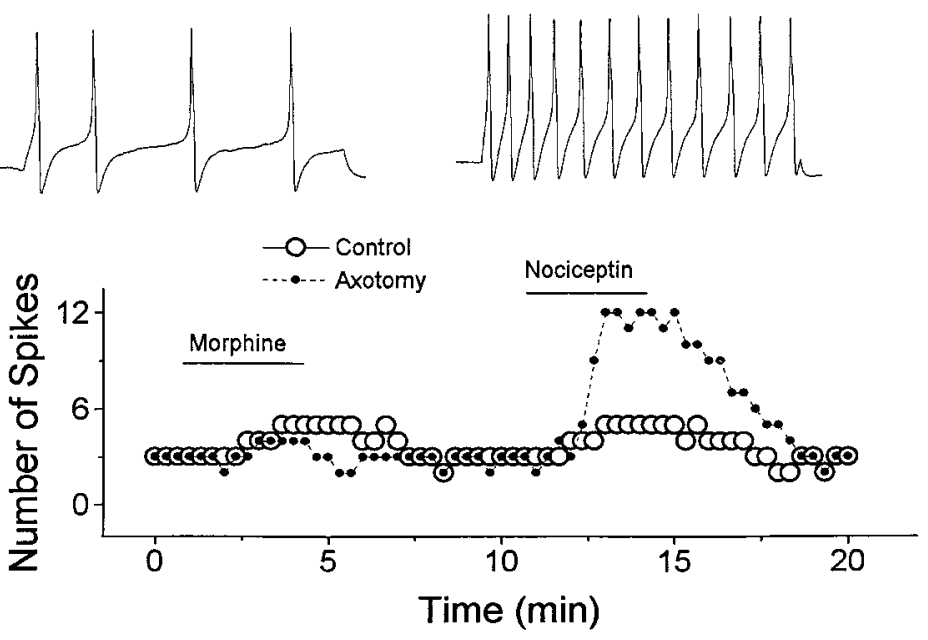
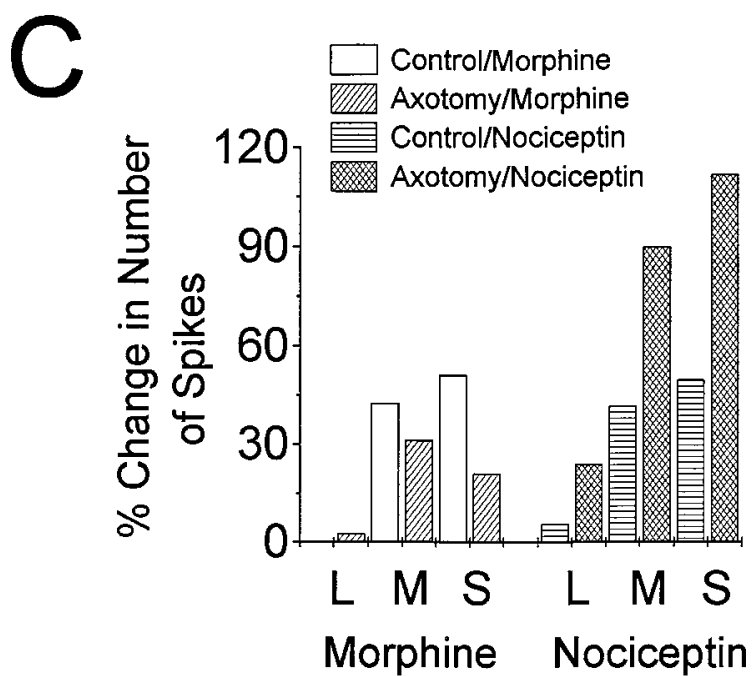

D

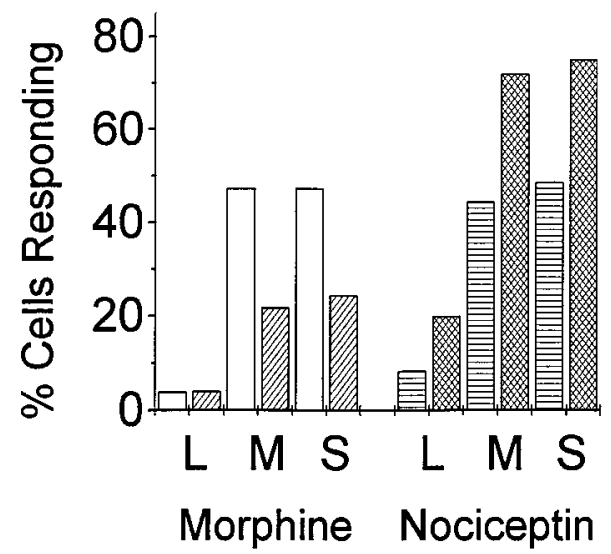

Figure 4. Effects of morphine or nociceptin on the excitability of DRG cells. $A$, Sample records from a control small cell $\left(A_{1}\right)$ and an axotomized small cell $\left(A_{2}\right)$ illustrating the effects of $1 \mu \mathrm{M}$ morphine and $1 \mu \mathrm{M}$ nociceptin on excitability. To generate APs, both cells were depolarized with a 1 sec pulse of current at threshold strength (current trace omitted for clarity). Note that both morphine and nociceptin increase the excitability of the control cell in a similar way; however, in the axotomized cell, the response to morphine was much less than the response to nociceptin. $B$, Time course of the effects of morphine and nociceptin on cells illustrated in $A_{1}$ and $A_{2}$ (data normalized). $C$, Graphs summarize effects of morphine or nociceptin on the percentage change in numbers of spikes discharged by $1 \mathrm{sec}$ pulses of current at threshold strength in large $(L)$, medium $(M)$, and small $(S)$ neurons from control or axotomized animals. $D$, Graphs show percentages of large, medium, and small neurons from control or axotomized animals that respond to morphine or nociceptin.

spinal analgesic in neuropathic pain is clearly worthy of further investigation.

The finding that morphine, DAMGO, U69593, and nociceptin exert their strongest effects on small and medium cells confirms and extends the previous results of Taddese et al. (1995) who showed that $\mu$-opioids have a preferential action on $g_{\mathrm{Ca}}$ of cells that are involved in the transfer of nociceptive information [also see Bessou and Perl (1969)]. Another factor that may contribute to the limited effectiveness of morphine in neuropathic pain is its inability to produce effects on large cells after axotomy (Fig.

$\leftarrow$

$I_{\mathrm{Ba}}$ suppression produced is seen most clearly from the time course graph. This shows amplitudes of successive $I_{\mathrm{Ba}}$ responses recorded once every 20 sec in the presence of morphine, nifedipine, and nifedipine plus morphine. Nifedipine reduces the total current but does not impair the action of morphine. $B$, Left-hand data records are from another small cell, again showing suppression of current by morphine. Right-hand data records comprise superimposed wash response (Wash) and current recorded in the presence of $\omega$-CTX GVIA and again in the presence of morphine plus $\omega$-CTX GVIA. The time course graph shows that morphine is much less effective in attenuating the total $I_{\mathrm{Ba}}$ in the presence of $\omega$-CTX GVIA. However, a clear reduction of the current is still observed. $C$, Data records and time course of an experiment performed with nociceptin and nifedipine. The ability of nociceptin to inhibit total $I_{\mathrm{Ba}}$ is not impaired by nifedipine. $D$, Data records and time course of an experiment performed with nociceptin and $\omega$-CTX GVIA. Although the toxin impairs nociceptin-induced $I_{\mathrm{Ba}}$ suppression, the effect is not completely blocked. 

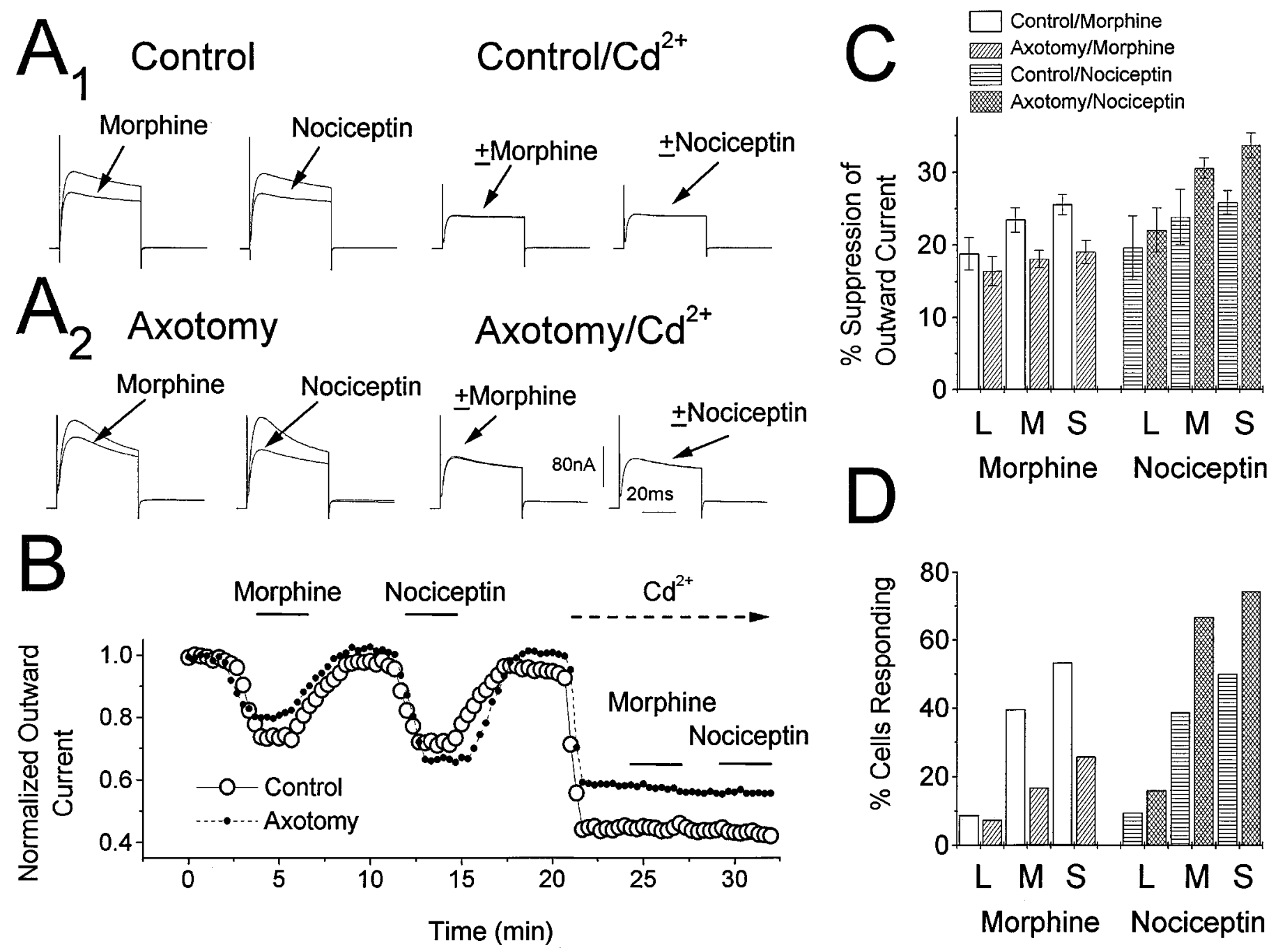

Figure 5. Effects of morphine or nociceptin (both $1 \mu \mathrm{M})$ on maximal outward current recorded at $+70 \mathrm{mV}\left(V_{\mathrm{h}}=-90 \mathrm{mV}\right)$. $A$, Superimposed data records of suppression of maximal outward current by $1 \mu \mathrm{M}$ morphine or nociceptin in a control $\left(A_{1}\right)$ and in an axotomized $\left(A_{2}\right)$ small cell (voltage commands omitted for clarity). After initial suppression and recovery of current by morphine or nociceptin, the current is again suppressed after superfusion of $1 \mathrm{mM} \mathrm{Cd}^{2+}$ to block $g_{\mathrm{K}}$, Ca responses. Note that in the control cell morphine and nociceptin produced similar effects on the outward current; however, after axotomy the effect of morphine was much smaller than that of nociceptin. Neither morphine nor nociceptin has effects on outward current recorded in the presence of $\mathrm{Cd}^{2+} . B$, Time course of the effects of morphine and nociceptin on cells illustrated in $A_{1}$ and $A_{2}$ (current is normalized for convenient comparison). $C$, Graphs summarizing effects of morphine and nociceptin $(1 \mu \mathrm{M})$ on maximal outward current amplitude in large $(L)$, medium $(M)$, and small $(S)$ neurons from control or axotomized animals. $D$, Graphs show percentages of large, medium, and small neurons from control or axotomized animals that respond to morphine or nociceptin (both $1 \mu \mathrm{M}$ ).

$1 C, D)$. This is because nerve injury promotes reorganization of non-nociceptive primary afferents so that they make contact with ascending nociceptive pathways in the dorsal horn (Woolf et al., 1982). Thus, innocuous sensory activity may be transmitted via pathways that normally carry nociceptive information. This may account for the phenomenon of mechanical allodynia, which sometimes accompanies peripheral nerve injury. The fact that nociceptin becomes more effective on all cell types, including large cells, after axotomy supports the idea that spinal administration of $\mathrm{ORL}_{1}$ agonists may be useful in the management of neuropathic pain. Interestingly, Hao et al. (1998) recently reported that intrathecal nociceptin dose-dependently alleviates mechanical and cold allodynia-like behavior in two different models of neuropathic pain.

Intrathecal (spinal) administration of nociceptin thus produces analgesia in various pain models (Henderson and McKnight, 1997; Hao et al., 1998), and some reports attest to its efficacy in neuropathic pain (Yamamoto et al., 1997; Jia et al., 1998). Despite this, there are conflicting reports as to the effect of intracerebroventricular administration. Although initial results suggested that intracerebroventricular nociceptin induced hyperalgesia (Meunier et al., 1995; Reinscheid et al., 1995), more recent studies (for review, see Henderson and McKnight, 1997) report analgesic actions, anti-opioid actions, and biphasic hyperalgesic/ analgesic effects. Any capacity of nociceptin to produce hyperalgesia presents something of a paradox because the vast majority of its cellular neurophysiological actions resemble those of classic, analgesic opioids, i.e., it decreases transmitter release, activates an inwardly rectifying $\mathrm{K}^{+}$conductance $\left(g_{\mathrm{KIR}}\right)$, and suppress HVA $g_{\mathrm{Ca}}$ in various types of spinal cord, brain, or DRG neurons (Connor et al., 1996a,b; Faber et al., 1996; Vaughan and Christie 1996, 1997; Abdulla and Smith, 1997b; Liebel et al., 1997; Vaughan et al., 1997). Such effects are indistinguishable from those of morphine (Jessell and Iversen, 1977; Cherubini and 
North, 1985; Hescheler et al., 1987; Williams et al., 1988; Surprenant et al., 1990; Schroeder et al., 1991; Hori et al., 1992; Moises et al., 1994a,b; Taddese et al., 1995; Womack and McCleskey, 1995). Unlike morphine, however, nociceptin suppresses T-type $\mathrm{Ca}^{2+}$ current in DRG neurons (Abdulla and Smith, 1997b), but any relevance of this observation to its reported, central hyperalgesic action remains to be established. Apart from the fact that sensitivity of DRG neurons to nociceptin was increased after axotomy whereas their sensitivity to morphine was decreased, we found no differences in the action of morphine and nociceptin. Both agonists affected $g_{\mathrm{Ba}, \mathrm{N}}$ and $\omega$-CTX GVIA/ nifedipine-resistant current to the same extent. Our findings therefore illustrate more similarity than difference between the cellular actions of morphine and nociceptin. Receptors for both agonists are preferentially expressed on small DRG cells, and each individual neuron that expresses $\mu$-receptors usually also expresses $\mathrm{ORL}_{1}$. Moreover, these two receptors seem to couple to exactly the same effectors. The observations that morphine suppresses the N- and non-N, non-L components of HVA $g_{\mathrm{Ca}}$ are similar to those previously reported with the selective $\mu$-receptor agonist PL017 (Rusin and Moises, 1995).

Spontaneous activity in damaged primary afferent fibers can contribute to chronic neuropathic pain (Devor et al., 1994). Such activity is enhanced by noradrenaline (Abdulla and Smith, 1997a) that is released from sympathetic nerves that sprout into axotomized ganglia (McLachlan et al., 1993). Although nociceptin suppresses $g_{\mathrm{Ca}, \mathrm{N}}$, reduces $g_{\mathrm{KCa}}$, and thereby excites axotomized DRG cells in a manner similar to noradrenaline (Fig. $4 A_{2}$ ), it still acts as an effective analgesic when it is administered intrathecally to nerve-injured rats (Yamamoto et al., 1997). This presumably reflects suppression of $g_{\mathrm{Ca}, \mathrm{N}}$ in primary afferent terminals (Liebel et al., 1997) and hyperpolarization of substantia gelatinosa neurons (Lai et al., 1997). Because its intracerebroventricular actions also remain to be resolved (Meunier et al., 1995; Reinscheid et al., 1995; Henderson and McKnight, 1997), nociceptin appears to exert only a clear analgesic effect at the spinal level. Any possible clinical use of $\mathrm{ORL}_{1}$ agonists in neuropathic pain would therefore be restricted to spinal routes of administration. This is not altogether infeasible because various techniques for chronic spinal administration of drugs in humans are now available (Du Pen, 1998).

\section{REFERENCES}

Abdulla FA, Smith PA (1997a) Ectopic $a_{2}$-adrenoceptors couple to $\mathrm{N}$-type $\mathrm{Ca}^{2+}$ channels in axotomized rat sensory ganglia. J Neurosci 17:1633-1641.

Abdulla FA, Smith PA (1997b) Nociceptin inhibits T-type $\mathrm{Ca}^{2+}$ channel current in rat sensory neurons by a G-protein independent mechanism. J Neurosci 17:8721-8728.

Abdulla FA, Smith PA (1997c) Differential effects of axotomy on the sensitivity of dorsal root ganglion (DRG) cells to morphine and nociceptin. Soc Neurosci Abstr 23:1016.

Abdulla FA, Smith PA (1999) Nerve injury increases an excitatory action of neuropeptide $\mathrm{Y}$ and $\mathrm{Y}_{2}$-agonists on dorsal root ganglion cells. Neuroscience, in press.

Akins PT, McCleskey EW (1993) Characterization of potassium currents in adult rat sensory neurons and modulation by opioids and cyclic AMP. Neuroscience 56:759-769.

Arners S, Megerson BA (1988) Lack of analgesic effect of opioids on neuropathic and idiopathic forms of pain. Pain 33:11-23.

Bessou P, Perl ER (1969) Response of cutaneous sensory units with unmyelinated fibres to noxious stimuli. J Neurophysiol 32:1025-1043.

Calo G, Rizzi A, Bodin M, Neugehauer W, Salvadori S, Guerrini R, Bianchi C, Regoli D (1997) Pharmacological characterization of nociceptin receptor: an in vitro study. Can J Physiol Pharmacol 75:713-718.
Cherubini E, North RA (1985) $\mu$ and $\kappa$ opioids inhibit transmitter release by different mechanisms. Proc Natl Acad Sci USA 82:1860-1863.

Connor M, Vaughan CW, Chieng B, Christie MJ (1996a) Receptors for nociceptin couple to an increase in potassium conductance in rat locus coeruleus neurons in vitro Br J Pharmacol 119:1614-1618.

Connor M, Yeo A, Henderson G (1996b) Nociceptin inhibits $\mathrm{Ca}^{2+}$ channel currents and elevates intracellular $\mathrm{Ca}^{2+}$ in the SH-SY5Y human neuroblastoma cell line. Br J Pharmacol 118:205-207.

De Groot JF, Coggeshall RE, Carlton SM (1997) The reorganization of $\mathrm{mu}$ opioid receptors in the rat dorsal horn following peripheral axotomy. Neurosci Lett 233:113-116.

Devor M, Janig W, Michaelis M (1994) Modulation of activity in dorsal root ganglion neurons by sympathetic activation in nerve-injured rats. J Neurophysiol 71:38-47.

Dunnill RJ, Kakizawa K, McKnight AT, Henderson G (1996) Characterization of the actions of naloxone benzoylhydrazone at $\mu$-opioid, $\kappa$-opioid and ORL1 receptors in isolated tissues from rat and guinea pig. Br J Pharmacol 119:275P.

Du Pen SL (1998) Implantable spinal catheter and drug delivery systems: complications. In: Complications of chronic pain therapy (Chan VWS, ed), pp 152-160. Philadelphia: Saunders.

Faber ESL, Chambers JP, Evans RH, Henderson G (1996) Depression of glutamatergic transmission by nociceptin in the neonatal rat hemisected spinal cord preparation in vitro, Br J Pharmacol 119:189-190.

Guerrini R, Calo G, Rizzi A, Bigoni R, Bianchi C, Salvadori S, Regoli D (1998) A new selective antagonist at the nociceptin receptor. Br J Pharmacol 123:163-165.

Hao JX, Xu IS, Wiesenfeld-Hallin Z, Xu XJ (1998) Anti-hyperanalgesic and anti-allodynic effects of intrathecal nociceptin/orphanin FQ in rats after spinal cord injury, peripheral nerve injury and inflammation. Pain 76 385-393.

Henderson G, McKnight AT, The orphan opioid receptor and its endogenous ligand: nociceptin/orphanin FQ Trends. Pharmacol Sci 18 293-300.

Hescheler J, Rosenthal W, Trautwein W, Schultz G (1987) The GTPbinding protein $G_{o}$ regulates neuronal calcium channels. Nature 325:445-447.

Hori Y, Endo K, Takahashi T (1992) Presynaptic inhibitory action of enkephalin on excitatory transmission in superficial horn of rat spinal cord. J Physiol (Lond) 450:673-685.

Iadarola MJ, Caudle RM (1997) Neuroscience: good pain, bad pain. Science 278:239-240.

Jessell TM, Iversen LL (1977) Opiate analgesics inhibit substance P release from rat trigeminal nucleus. Nature 268:549-551.

Jia YP, Linden DR, Serie JR, Seybold VS (1998) Nociceptin/orphanin FQ binding increases in superficial laminae of the rat spinal cord during persistent peripheral inflammation. Neurosci Lett 250 21-24.

Lai CC, Wu SY, Dun SL, Dun NJ (1997) Nociceptin-like immunoreactivity in the rat dorsal horn and inhibition of substantia gelatinosa neurons. Neuroscience 81:887-891.

Liebel JT, Swandulla D, Zeilhofer HU (1997) Modulation of excitatory synaptic transmission by nociceptin in superficial dorsal horn neurones of the neonatal rat spinal cord. Br J Pharmacol 121:425-432.

Martin WR (1983) The pharmacology of opioids. Pharmacol Rev 35:285-323

McLachlan EM, Janig W, Devor M, Michalis M (1993) Peripheral nerve injury triggers noradrenergic sprouting within dorsal root ganglia. Nature 363:543-546.

Meunier JC, Mollereau C, Toll L, Suaudeau C, Moisand C, Alvinerie P, Butour JL, Guillemot JC, Ferrara P, Monsarrat B, Mazarguil H, Vassart G, Parmentier M, Costentin J (1995) Isolation and structure of the endogenous agonist of opioid receptor-like ORL1 receptor. Nature 377:532-535.

Moises HC, Rusin KI, Macdonald RL (1994a) $\mu$-Opioid receptor mediated reduction of neuronal calcium current occurs via a $\mathrm{G}_{\mathrm{o}}$-type GTPbinding protein. J Neurosci 14:3842-3852.

Moises HC, Rusin KI, Macdonald RL (1994b) $\mu$ and $\kappa$-opioid receptors selectively reduce the same transient components of high threshold calcium current in rat dorsal root ganglion sensory neurons. J Neurosci 14:5903-5916.

Nichols ML, Bian D, Ossipov MH, Lai J, Porreca F (1995) Regulation of morphine antiallodynic efficacy by cholecystokinin in a model of neuropathic pain in rats. J Pharmacol Exp Ther 275:1339-1345.

Nothacker HP, Reinscheid RK, Mansour A, Henningsen RA, Ardati A, Monsma FJ, Watson SJ, Civelli O (1996) Primary structure and tissue 
distribution of the orphanin FQ precursor. Proc Natl Acad Sci USA 93:8677-8682.

Ossipov MH, Lopez Y, Nichols ML, Bian D, Porreca F (1995) Inhibition by spinal morphine of the tail-flick response is attenuated in rats with nerve ligation injury. Neurosci Lett 199:83-86.

Paternak GW (1993) Pharmacological mechanisms of opioid analgesics. Clin Neuropharmacol 16:1-18.

Reinscheid RK, Nothacker HP, Bourson A, Ardati A, Henningsen RA, Bunzow JR, Grandy DK, Langen H, Monsma Jr FJ, Civelli O (1995) Orphanin FQ: a neuropeptide that activates an opioid-like G-protein coupled receptor. Science 270:792-794.

Rusin KI, Moises HC (1995) $\mu$-Opioid receptor activation reduces multiple components of high threshold calcium current in rat sensory neurons. J Neurosci 15:4315-4327.

Schroeder JE, Fischbach PS, Zheng D, McCleskey EW (1991) Activation of opioid receptors inhibits transient high and low threshold $\mathrm{Ca}^{2+}$ currents but spares a sustained current. Neuron 6:13-20.

Surprenant A, Shen KZ, North RA, Tatsumi H (1990) Inhibition of calcium currents by noradrenaline, somatostatin and opioids in guinea pig submucosal neurons. J Physiol (Lond) 431:585-608.

Swett JE, Torigoe Y, Elie VR, Bourassa CM, Miller PG (1991) Sensory neurons of the rat sciatic nerve. Exp Neurobiol 114:82-103.

Taddese A, Nah SY, McCleskey EW (1995) Selective opioid inhibition of small nociceptive neurons. Science 270:1366-1368.

Vaughan CW, Christie MJ (1996) Increase by the ORL 1 receptor (opioid receptor-like ${ }_{1}$ ) ligand, nociceptin, of inwardly rectifying $\mathrm{K}^{+}$conductance in dorsal raphe nucleus neurons. $\mathrm{Br} \mathrm{J}$ Pharmacol 117:1609-1611.

Vaughan CW, Christie MJ (1997) Presynaptic inhibitory action of opioids on synaptic transmission in the rat periaqueductal grey in vivo. J Physiol (Lond) 498:463-472.

Vaughan CW, Ingram SL, Christie MJ (1997) Actions of the ORL receptor ligand nociceptin on membrane properties of rat periaqueductal gray neurons in vitro. J Neurosci 17:996-1003.

Wegert S, Ossipov MH, Nichols ML, Bian D, Vanderah TW, Malan TP, Porreca F (1997) Differential activities of intrathecal MK-801 or mor- phine to alter responses to thermal and mechanical stimuli in normal or nerve-injured rats. Pain 71:57-64.

Werz MA, MacDonald RL (1982) Opioid peptides decrease calcium dependent action potential duration of mouse dorsal root ganglion neurons in cell culture. Brain Res 239:315-321.

Werz MA, Grega DS, MacDonald RL (1987) Actions of $\mu, \kappa$, and $\delta$ opioid agonists and antagonists on mouse primary afferent neurons in culture. J Pharmacol Exp Ther 243:258-263.

White G, Lovinger DM, Weight FF (1989) Transient low-threshold $\mathrm{Ca}^{2+}$ current triggers burst firing through an afterdepolarizing potential in adult mammalian neurones. Proc Natl Acad Sci USA 86:6802-6806.

Williams JT, North RA, Tokimasa T (1988) Inward rectification of resting and opiate activated potassium conductance in rat locus coeruleus neurons. J Neurosci 8:4299-4306.

Womack MD, McCleskey EW (1995) Interaction of opioids and membrane potential to modulate $\mathrm{Ca}^{2+}$-channels in rat dorsal root ganglion neurons. J Neurophysiol 73:1793-1798.

Woolf CJ, Shortland P, Coggeshall RE (1982) Peripheral nerve injury triggers central sprouting of myelinated afferents. Nature 355:75-78.

Yamamoto T, Nozaki Taguchi N (1996) Clonidine, but not morphine, delays the development of thermal hyperesthesia induced by sciatic nerve constriction injury in the rat. Anesthesiology 85:835-845.

Yamamoto T, Nozaki Taguchi N, Kimura S (1997) Effects of intrathecally administered nociceptin, an opioid receptor-like ${ }_{1}\left(\mathrm{ORL}_{1}\right)$ receptor agonist, on the thermal hyperalgesia induced by unilateral constriction injury to the sciatic nerve in the rat. Neurosci Lett 224:107-110.

Zhang X, Bao L, Arvidsson U, Elde R, Hokfelt T (1998a) Localization and regulation of the delta opioid receptor in dorsal root ganglia and spinal cord of the rat and monkey: evidence for association with the membrane of large dense core vesicles Neuroscience 82:1225-1242.

Zhang X, Bao L, Shi TJ, Ju G, Elde R, Hokfelt T (1998b) Down regulation of mu opioid receptors in rat and monkey dorsal root ganglion neurons and spinal cord after peripheral axotomy. Neuroscience 82:223-240. 